IRA-International Journal of Management \& Social Sciences

ISSN 2455-2267; Vol.06, Issue 03 (2017)

Pg. no. 461-466

Institute of Research Advances

https://research-advances.org/index.php/RAJMSS

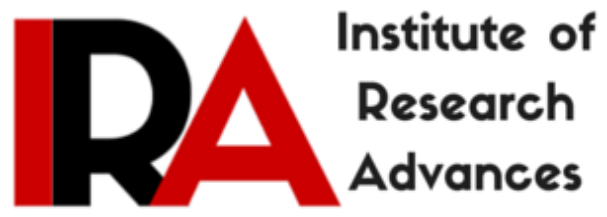

\title{
A Study on the Implications of Pradhan Manthri Jan Dhan Yojana on the Growth of Indian Economy
}

T. Mary Jones ${ }^{1}$

Associate Professor and Head,

Department of MBA, PACE Institute of Technology \& Sciences, Vallure, India.

\section{S. DivyaSri ${ }^{2}$}

MBA-II

PACE Institute of Technology \& Sciences, Vallure, India.

\section{G. Bavani ${ }^{3}$}

MBA-II

PACE Institute of Technology \& Sciences, Vallure, India.

Type of Review: Peer Reviewed.

DOI: http://dx.doi.org/10.21013/jmss.v6.n3.p11

\section{How to cite this paper:}

Jones, T., DivyaSri, S., \& Bavani, G. (2017). A Study on the Implications of Pradhan Manthri Jan Dhan Yojana on the Growth of Indian Economy. IRA-International Journal of Management \& Social Sciences (ISSN 2455-2267), 6(3), 461-466. doi:http://dx.doi.org/10.21013/jmss.v6.n3.p11

(C) Institute of Research Advances

\section{(cc) EY-NC}

This work is licensed under a Creative Commons Attribution-Non Commercial 4.0 International License subject to proper citation to the publication source of the work.

Disclaimer: The scholarly papers as reviewed and published by the Institute of Research Advances (IRA) are the views and opinions of their respective authors and are not the views or opinions of the IRA. The IRA disclaims of any harm or loss caused due to the published content to any party. 


\section{ABSTRACT}

Indians are transforming from rural India to digital India with so many initiatives by the Central government of our country. The initiatives like Make In India, Jan Dhan Yojana, Swatch Bharat, Demonetization Of Currency are all contributing for the growth of Indian economy. These schemes are to improve the productivity of our country and also for proving a better standard of living for Indians. India is a strong nation with more than 50\% of its people is in the working age. With this strength we can achieve success if we work hard with strict rules and regulations. Thus this paper is focusing on the implications of PMJDY scheme in the scenario of developmental aspects across India.

Keywords: Jan Dhan Yojana, PMJDY, Demonetization of Currency, Digitalization

\section{Introduction:}

India is identified as fastest growing economy. One of the main reasons that contribute for this is Digitalization. Today we are living in digital era. Digitalization is the key word that is heard in every part of the world and especially it is the motto of present India. We want to make our country as Digital India. Our government is taking many initiatives to make this change successfully. Digitalization is the use of technologies to provide new revenues to the business and the country as a whole. Use of digital technologies can be made in every form of organization. Thus this is making India to become fastest growing economy in the recent past. The fast growing industries like software, e-business, and pharmaceuticals are all playing the key role in the development of Indian economy. But this is applicable to only those who can use the digital technologies and the financial services.
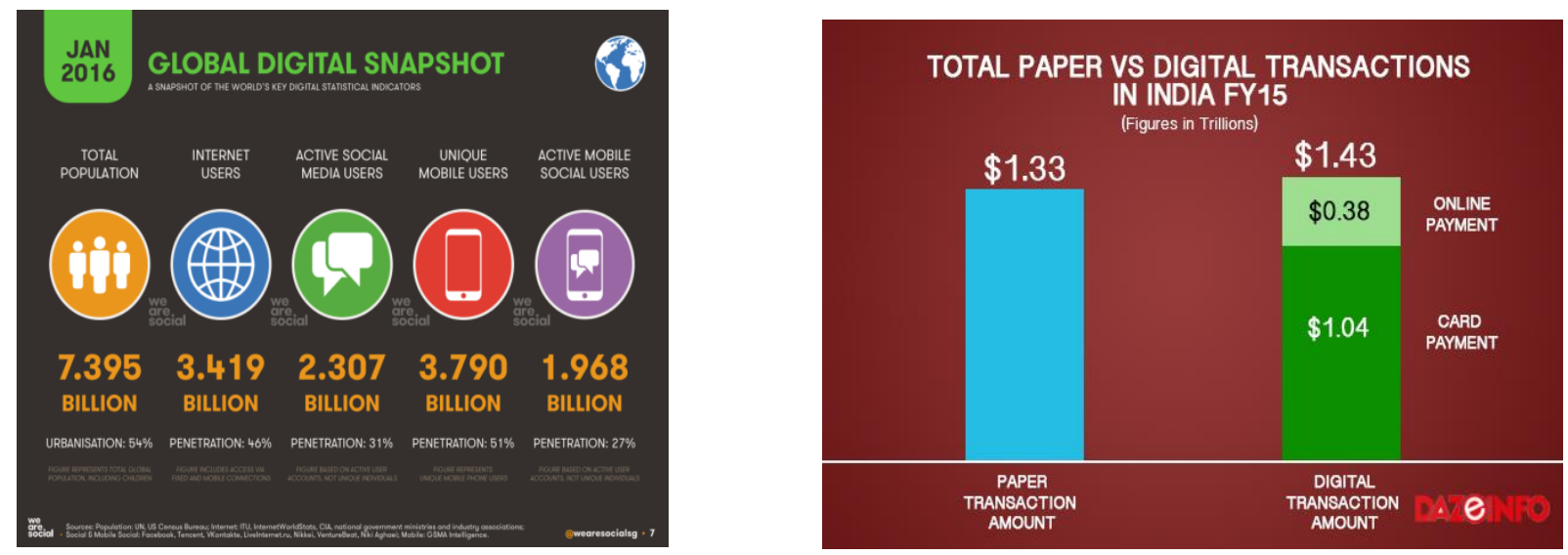

In this regard the government of India concentrated on the concept of financial inclusion for the benefit of all the people of our country. Financial inclusion is the process of providing all the financial services at affordable costs to sections of disadvantaged and low-income segments of the country. But to provide the financial services all the people should have access to banks which indicates the need for bank account for every Indian. Pradhan Manthri Jan Dhan Yojana is aimed at this objective. That is to make every Indian a bank account holder.

\section{Literature of Review:}

(Dr. Sudhinder Singh Chowhan, 2014) - This paper focuses on the launch of Jan Dhan Yojana scheme for all Indians and its impact on the improvement of living standards of all the people as a part of Financial Inclusion which emerged in 2000. Financial inclusion helps in providing the financial services like banking facilities to all the citizens. 
(Dr.B.C.M. Patnaik, 2015) - This study is mainly focused on the respondents' opinion on opening bank accounts as per the national mission of "PMJDY". The study was conducted to Eastern region of India and capital region of Odisha comprising household servants, labourers, taxi drivers contractual staff etc., It is observed from the sample that the people are not interested to open bank accounts as they do not have savings to deposit. Thus awareness camps are required to create interest in people to open bank accounts.

(Rai, 2015) - This focus of the paper is to analyse PMJDY scheme as many Indians are not still availing bank accounts. They are all out of the growth sector or in unorganized financial system which does not directly contribute to the development of our country.

(Raval, 2015) - The financial system affects the growth rate of our country. But most of the Indians are not a part of this development. Thus PMJDY is an innovative initiative to increase the contributions of Indians for the sake of our country.

(Guntupalli, 2016) - This study is mainly focused on identifying the role of government and banks to implement and encourage the people to actively participate in PMJDY. The study identifies that the low income received by the people is making it difficult to open the accounts and continue the transactions through banks.

(Dr. C. Paramasivan, 2015) - This study is exclusively focusing on the role of public sector banks in the implementation of the national mission "PMJDY" and it is observed that they are working well.

(Dheeraj Agrawal, 2015) - The study is based on the opinions collected from individuals and reports of Canara Bank. The study identifies that this initiative is considered as a stepping stone for the growth of Indian economy as it provides easy access to banking services for the weaker section people.

(Aswathy V K, 2015) - . This paper focuses on the measures initiated by RBI for better Financial Inclusion and the extent to which the Pradhan Mantri Jan Dhan Yojana is contributing to it. The study found that the many people have opened bank accounts due to the scheme.

(DAS, 2015) - This study focuses on identifying the effectiveness of innovative schemes like MGNREGA and PMJDY. The study resulted that the financial transactions have improved for the poor sections also.

\section{Objectives of the Study:}

- To study the implications of Jan Dhan Yojana in the case of demonetization.

- To study the impact of Jan Dhan Yojana in the growth of Indian economy.

\section{Research Methodology:}

- The study is conducted basing on secondary data that is books, journals, magazines and the reports published by RBI, Public sector banks etc. 


\section{Analysis and Interpretation:}

Pradhan Mantri Jan - Dhan Yojana

(Accounts Opened as on 30.11.2016)

(All Figures in Crores)

\begin{tabular}{|l|l|l|l|l|l|l|l|}
\hline $\begin{array}{l}\text { Bank } \\
\text { Name }\end{array}$ & RURAL & URBAN & TOTAL & $\begin{array}{l}\text { NO OF } \\
\text { RUPAY } \\
\text { CARDS }\end{array}$ & $\begin{array}{l}\text { AADHAAR } \\
\text { SEEDED }\end{array}$ & $\begin{array}{l}\text { BALANCE } \\
\text { IN } \\
\text { ACCOUNTS }\end{array}$ & $\begin{array}{l}\text { \% } \\
\text { ZERO- } \\
\text { BALANCE- } \\
\text { ACCOUNTS }\end{array}$ \\
\hline $\begin{array}{l}\text { Public } \\
\text { Sector } \\
\text { Bank }\end{array}$ & 11.44 & 9.07 & 20.51 & 15.60 & 11.51 & 57939.75 & 22.93 \\
\hline $\begin{array}{l}\text { Regional } \\
\text { Rural } \\
\text { Bank }\end{array}$ & 3.79 & 0.62 & 4.41 & 2.95 & 2.07 & 13682.12 & 20.10 \\
\hline $\begin{array}{l}\text { Private } \\
\text { Banks }\end{array}$ & 0.52 & 0.34 & 0.86 & 0.81 & 0.37 & 2699.69 & 34.92 \\
\hline Total & 15.75 & 10.03 & 25.78 & 19.36 & 13.95 & 74321.55 & 22.85 \\
\hline
\end{tabular}

Once the scheme has been announced the number of accounts opened was very high. Within two years the total number of accounts opened was 25.78 crores with 74321.55 crores in their accounts. In order to operate these accounts the banking operations are being extended into rural India. The number of people who are using debit cards and ATMs are being increased vastly. The number of people who are involved in e-commerce through digital resources is increasing at a very faster rate.

\begin{tabular}{|l|l|l|}
\hline & No of ATMs & No. of Debit cards \\
\hline Jun-12 & 99218 & 290677993 \\
\hline Jun-14 & 166894 & 409034442 \\
\hline Jun-16 & 201335 & $\mathbf{6 9 1 1 4 2 1 5 7}$ \\
\hline
\end{tabular}

\section{The Present Scenario:}

Recently the government of India came with a new surgical attack on our economy in the form of demonetization. The bigger notes 500/- and 1000/- have been banned. Suddenly the monetary situation has become complicated. Without the supply of currency all the business transactions have been stumbled. Everybody is now forced to make use of digital services. Previously even if you are having accounts, most of them are performing the transactions through paper directly approaching the bank. But now banks are also not in a position to conduct these operations. But to have digital payments we need to first have an account. But most of the rural India is not with a single bank account until recent past. But the scheme PMJDY has allowed them to create new accounts thus pouring money into banks and also to avail a Rupay card. 
This act was claimed as an effort to stop the current banknotes for funding terrorism and also to reduce the black money in the country. India ranks $76^{\text {th }}$ in the corruption perceived index. To curb corruption our government took this initiative. Thus the move was a step towards development of India. But the sudden decision was a big problem to all the people. The banks were short of cash and ATMs were always out of cash. It became a big burden for all common people, business people, offices etc. Now the only way to get cash, or exchange old notes with the new one is done by only banks and post offices. This is easily possible if you have account with them. Thus all the people who opened their accounts can get maximum benefits from banks. At the same time they are also having overdraft facility on their PMJDY accounts. So they can get money from these banks also.

\section{Limitations of PMJDY:}

- Jan Dhan Yojana created Guinness record in the opening of accounts. But at the same time the dormancy rate is also high in these accounts when compared to other accounts.

- $22 \%$ of the people are maintaining zero balance accounts which ensure that the circulation of currency will be less.

- Number of people who opened account in this scheme and their share of using digital services in banks is truly less.

- Most of the people are not still aware of the benefits of financial inclusion which is making them to be far from banking transactions.

\section{Conclusion:}

PMJDY scheme is very useful to all the people and especially in the scenario of demonetization of currency. With this scheme many people have become bank account holders and thereby are able to enjoy the benefits provided by the government through banks. But the government should take initiatives to reduce the dormancy of these accounts, thereby increasing the pace of transforming India into Super Power in the near future.

\section{References:}

1. Aswathy V K, S. V. (2015). PMJDY: A BOLD PATH WAY FOR FINANACIAL INCLUSION. International Journal of Business and Administration Research Review , 126-132.

2. DAS, A. N. ( 2015). FINANCIAL INCLUSION THROUGH TWO SELECTIVE INNOVATIVE INTERLINKAGE MECHANISMS . INTERCONTINENTAL JOURNAL OF BANKING, INSURANCE AND FINANCE , 20-26.

3. Dheeraj Agrawal, T. S. (2015). Prospering Indian Economy through Expansion of Financial Inclusion Schemes: With Special Reference to Pradhan Mantri Jan Dhan Yojana. Advances in Economics and Business Management (AEBM), 1169-1173.

4. Dr. C. Paramasivan, R. K. (2015). PUBLIC SECTOR BANKS PERFORMANCE AND CONTRIBUTION ON PRADHAN MANTRI JAN DHAN . International Journal in Commerce, IT \& Social Sciences , 16-23.

5. Dr. Sudhinder Singh Chowhan, I. J. (2014). Pradhan Mantri Jan Dhan Yojana: A Giant Leap Towards Financial Inclusion. International Journal of Research in Management \& Business Studies (IJRMBS 2014) , 19-22.

6. Dr.B.C.M. Patnaik, D. I. (2015). PRADHAN MANTRI JAN DHAN YOJNA (PMJDY) - A NEW DIRECTION FOR MAINSTREAMING THE FINANCIALLY EXCLUDED . National Journal of Management (IJM), ISSN 0976 - 6502(Print), ISSN 097 , 31-42. 
7. Guntupalli, P. S. (2016). Exploring the impacts of "Pradhan Mantri Jan-Dhan Yojana'- PMJDY, in urban areas, w.r.t. Mumbai . IOSR Journal of Economics and Finance (IOSR-JEF) , 82-86.

8. Rai, D. S. ( 2015). PRADHAN MANTRI JAN DHAN YOJNA: AN AMBITIOUS PLAN FOR FINANCIAL INCLUSION. RESEARCH FRONT , 25-32.

9. Raval, D. H. (2015). Shaping New India through Financial Inclusion in form of PMJDY . International Journal of Research in Humanities \& Social Sciences , 34-38. 